\title{
PENGARUH ABDOMINAL ACUPUNCTURE TERHADAP PENURUNAN BERAT BADAN PADA KLIEN BERAT BADAN BERLEBIH DI GRIYA SEHAT PRIMA HATI SURAKARTA
}

\author{
Maria Dewi Christiyawati \\ Kementerian Kesehatan Politeknik Kesehatan Surakarta Jurusan Akupunktur
}

\begin{abstract}
Abdominal Acupuncture, Overweight. Overweight is a disorder characterized by accumulation of excess body fat tissue. Thuss it is necessary to be treated seriously. One of the most effective treatment for weight loss is acupuncture. Therefore the purpose of this study is to determine the effect of abdominal acupuncture method one of acupuncture method for weight loss in overweight clients. This method is a quasi-experimental research design with one group pre-post test design. The research is conducted in Griya Sehat Prima Hati Surakarta with 20 people as sample which obtained from total sampling. Data were analyzed by paired T-test with significance level of 0.05 . The result of this research found that the average loss weight is $2,20 \pm 1,05 \mathrm{~kg}(p<0,05)$, which means that $\mathrm{Ho}$ is rejected and $\mathrm{Ha}$ is accepted. It can be concluded that there is an effect of abdominal acupuncture method to lose weight in overweight clients.
\end{abstract}

Keywords: Abdominal Acupuncture, Overweight

\begin{abstract}
Abstrak : Abdominal Acupuncture, Berat Badan Berlebih. Berat badan berlebih merupakan kelainan yang ditandai dengan penimbunan jaringan lemak tubuh secara berlebihan. Prevalensi di dunia dan khususnya di Indonesia meningkat setiap tahunnya. Berat badan berlebih dapat memicu sejumlah penyakit kronis seperti diabetes mellitus, penyakit jantung, oeteoartritis dan kanker. Maka dari itu diperlukan penanganan secara baik. Salah satu penanganan yang cukup efektif untuk penurunan berat badan adalah akupunktur. Tujuan penelitian ini untuk mengetahui pengaruh metode abdominal acupuncture yang merupakan salah satu teknik akupunktur untuk penurunan berat badan pada berat badan berlebih. Penelitian ini merupakan penelitian eksperimental semu dengan rancangan penelitian one group pre -post test design. Penelitian dilakukan di Griya Sehat Prima Hati Surakarta. Dengan jumlah sampel 20 orang. Yang didapat secara total sampling. Data dianalisis dengan uji Paired T-Test dengan signifikansi 0,05. Hasil penelitian ini didapatkan rata - rata penurunan berat badan 2,20 $\pm 1,05 \mathrm{~kg}(p<0,05)$, setelah di uji secara statistik $\mathrm{p}$ value $<0,001<0,05$ yang artinya Ho ditolak dan Ha diterima, dan dapat disimpulkan ada pengaruh metode abdominal acupuncture terhadap penurunan berat badan pada berat badan berlebih.
\end{abstract}

Kata Kunci : Abdominal Acupuncture, Berat Badan Berlebih 


\section{PENDAHULUAN}

Kelebihan berat badan (overweight) diibaratkan seperti fenomena "gunung es", dimana keadaan yang tampak di permukaan hanya sedikit, sedangkan di dalamnya terdapat masalah yang besar bagi kesehatan. Kelebihan berat badan tidak hanya mengganggu penampilan seseorang, tetapi kini merupakan masalah yang serius karena kelebihan lemak tubuh yang tertimbun sehingga menimbulkan dampak merugikan bagi kesehatan dan memicu timbulnya berbagai komplikasi penyakit yang menyertainya (Sumanto, 2009; WHO, 2015).

Berdasarkan data WHO (2015) menyebutkan bahwa pengumpulan data di seluruh dunia pada tahun 2014, lebih dari 1,9 miliar orang dewasa mengalami kelebihan berat badan dan 600 juta diantaranya mengalami obesitas. Prevalensi kelebihan berat badan dan obesitas di seluruh dunia lebih dari dua kali lipat antara tahun 1980 dan 2014. Di negara-negara berkembang dengan ekonomi menengah (diklasifikasikan oleh Bank Dunia sebagai negara berpenghasilan menengah) angka kejadian kelebihan berat badan sudah lebih dari 30\% lebih tinggi dari negara-negara maju. Menurut Wirawan (2011) ada sekitar $61 \%$ penduduk Amerika memiliki kelebihan berat badan dan 25\% diantara penduduk Amerika mengalami kegemukan (obesitas). Sedangkan di Indonesia, menurut data Riset Kesehatan Dasar (Riskesdas) pada tahun 2007, prevalensi nasional obesitas umum pada penduduk berusia $\geq 15$ tahun adalah 10,3\% (laki-laki 13,9\%, perempuan 23,8\%) (Depkes, 2009).
Akupunktur merupakan cara pengobatan dengan cara menusuk jarum dan merupakan salah satu pengobatan medis tertua dan paling umum yang digunakan di dunia, yang berasal dari Cina (Saputra, 2005). Akupunktur dapat memberikan efek diantaranya mengurangi rasa lapar, meningkatkan metabolisme tubuh, mengontrol hormon dan pencernaan serta dapat mengendalikan stress. Selain itu, akupunktur juga tidak memiliki efek samping ataupun membuat pasien kecanduan (Hecker, Steveling, dan Peuker, 2006). Pengaturan diet dan aktivitas fisik masih menjadi tata laksana utama kegemukan. Kualitas asupan dapat diperbaiki dengan mengurangi konsumsi makanan padat energi contohnya makanan yang tinggi lemak dan gula, serta dengan meningkatkan asupan serat (Imaz et al., 2008; Haslam dan James, 2005). Untuk itu, pengobatan akupunktur dapat dijadikan pilihan sebagai pengobatan komplementer untuk menangani masalah kelebihan berat badan. Berdasarkan penjelasan tersebut, maka penulis tertarik untuk melakukan penelitian dengan judul pengaruh abdominal acupuncture terhadap berat badan pada klien berat badan berlebih di Griya Sehat Prima Hati Surakarta.

\section{METODE PENELITIAN}

Jenis penelitian yang digunakan adalah eksperimental semu yang artinya bila peneliti tidak mungkin mengontrol semua variable lur, sehingga perubahan yang terjadi pada efek tidak sepenuhnyta dipengaruhi perlakuan (Nursalam,2003). Rancangan penelitian menggunkan "One Group Pretest - Postest Design “. Sebelum 
dilakukan abdominal acupuncture di ukur berat badan dan tinggi badan kemudian dihitung indeks massa tubuh, yang termasuk dalam kategori berat badan berlebih kemudian diberikan perlakuan. Setelah diberikan abdominal acupuncture diukur berat badannya kembali, apakah ada perbedaan berat badan sebelum dan sesudah diberikan perlakuan. Perbedaan antara sebelum dan setelah perlakuan di sebut sebagai efek dari tindakan/ekperimen (Nursalam, 2003)

Tempat dan waktu penelitian, penelitian dilakukan di Griya Sehat Prima Hati Surakarta. Waktu penelitian adalah bulan Desember 2016 - April 2017. Populasi dalam penelitian ini adalah semua klien yang mengalami berat badan lebih di Griya Sehat Prima Hati pada periode bulan Januari - Februari 2017 berjumlah 20 orang. Pemilihan sampel menggunakan total sampling dan disesuaikan dengan kriteria inklusi dan eksklusi. Adapun kriteria inklusi adalah sebagai berikut, klien Griya Sehat Prima Hati Surakarta, Klien perempuan ataupun laki - laki dengan berat badan berlebih, IMT $23,0-24,9 \mathrm{~kg} / \mathrm{m}^{2}$, dapat berkomunikasi dengan baik, tidak memiliki penyakit penyerta, klien tidak sedang menjalani terapi penurunan berat badan yang lain. Kriteria eksklusi, klien yang mengundurkan diri, klien yang tidak mengikuti jadwal terapi secara teratur, klien yang selama menjalankan program terapi melakukan program terapi lain. Variabel penelitian, variable dependen dalam penelitian ini adalah berat badan. Variabel independen adalah abdominal acupuncture. Alat dan bahan dalam penelitian ini menggunakan timbangan berat badan
(Camry Model Jarum), jarum akupunktur, elektrostimulator, pita ukur, alcohol $70 \%$, pinset, bengkok, kapas steril. Pengambilan data penelitian dilakukan dengan mencatat hasil pengukuran berat badan dan tinggi badan sebelum terapi, dan 2 hari setelah terapi ke 10. Cara pengolahan data dan analisa data, pengolahan data pada penelitian ini akan dilaksanakan dengan tahap editing dan tabulating. Analisa data pada penelitian ini, penulis melakukan uji normalitas data, dan apabila data berdistribusi normal dianilis menggunakan analisis dependent sample $T$ test. Melalui analis tersebut akan diketahui perbedaan sebelum dan setelah perlakuan sampel.

\section{HASIL PENELITIAN}

berikut,

Hasil penelitian adalah sebagai

Distribusi Responden Berdasarkan Jenis Kelamin Di Griya Sehat Prima Hati Surakarta Februari 2017

\begin{tabular}{lcc}
\hline Jenis Kelamin & Frekwensi & Persentase \\
\hline Laki - laki & 4 & 22 \\
Perempuan & 16 & 78 \\
Total & $\mathbf{2 0}$ & $\mathbf{1 0 0}$ \\
\hline
\end{tabular}

Tabel 2

Distribusi Responden Penelitian Berdasarkan Tinggi Badan Di Griya Sehat Prima Hati Surakarta Februari 2017

\begin{tabular}{lcccc}
\hline Variabel & Means & SD & $\begin{array}{c}\text { Min- } \\
\text { Max }\end{array}$ & 95\% CI \\
\hline Tinggi Badan & 154,00 & 5,640 & $145-$ & $151,50-$ \\
& & & 167 & 156,50 \\
\hline
\end{tabular}


Tabel 3

Distribusi Responden Penelitian

Berdasarkan Berat Badan Di Griya Sehat Prima Hati Surakarta Februari 2017

\begin{tabular}{lcccc}
\hline Variabel & Means & SD & $\begin{array}{l}\text { Min- } \\
\text { Max }\end{array}$ & 95\% CI \\
\hline Berat Badan & 57,27 & 4,300 & $50-$ & $55,37-$ \\
& & & 60 & 59,18 \\
\hline
\end{tabular}

Tabel 4

Distribusi Responden Penelitian Berdasarkan Imt Di Griya Sehat Prima Hati Surakarta Februari 2017

\begin{tabular}{lcrrr}
\hline Variabel & Means & SD & $\begin{array}{c}\text { Min- } \\
\text { Max }\end{array}$ & $\mathbf{9 5 \% C I}$ \\
\hline IMT & 24,12 & 0,55 & $23,19-$ & $23,87-$ \\
& & & 24,88 & 24,36 \\
\hline
\end{tabular}

Tabel 5

Distribusi Responden Penelitian

Berdasarkan Berat Badan Setelah

Terapi Di Griya Sehat Prima Hati Surakarta Februari 2017

\begin{tabular}{lcccc}
\hline Variabel & Means & SD & $\begin{array}{c}\text { Min- } \\
\text { Max }\end{array}$ & 95\% CI \\
\hline Berat Badan & 54,91 & 4,482 & $48-$ & $52,92-$ \\
& & & 67 & 56,90 \\
\hline
\end{tabular}

Tabel 6.

Distribusi Responden Penelitian

Berdasarkan Berat Badan Sebelum Dan

Setelah Terapi Di Griya Sehat Prima Hati Surakarta Februari 2017

\begin{tabular}{lrrrr}
\hline Variabel & Means & SD & SE & $\begin{array}{l}\text { P } \\
\text { Value }\end{array}$ \\
\hline Berat Badan & & & & \\
Sebelum terapi & 57,27 & 4,300 & 0,917 & 0.000 \\
Setelah terapi & 54,91 & 4,482 & 0,956 & \\
\hline
\end{tabular}

\section{PEMBAHASAN}

Berat badan sebelum dan setelah di terapi ini adalah data untuk penentuan data distribusinya. Data distribusi dapat di lihat selain melalui diagram histogram. Pada data berat badan sebelum terapi diketahui nilai skewness 0,913 dibagi standar eror 0,491 yaitu 1,85 maka data distribusinya normal. Pada data berat badan setelah terapi diketahui nilai Skewness 0,928 dibagi standar eror 0,491 yaitu 1,89 maka data berdistribusi normal.

Dari hasil penelitian didapatkan data kemudian dianalisis menggunakan uji dependent $\mathrm{t}$ test. Hasil statistic didapatkan perbedaan nilai means sebelum dengan sesudah terapi yaitu rata - rata berat badan sebelum terapi adalah $57,27+4,300 \mathrm{~kg}$. Pada pengukuran berat badan setelah terapi didapatkan beda bermakna adalah $54,91 \pm$ $4,482 \mathrm{~kg}$ hal ini berarti bahwa ada pengaruh metode abdominal acupuncture terhadap penurunan berat badan pada klien berat badan berlebih. Hasil penelitian ini sesuai dengan kajian teori yang telah dibahas pada tinjauan pustaka. Pada ilmu kedokteran China, membahas tentang teori berat badan berlebih dan obesitas merupakan tanggung jawab organ limpa dan lambung. Sesuai fungsinya secara TCM adalah sebagai penerima dan pencerna makanan, kemudian mengolah dan mendistribusikan hasil olahan dari makanan. Organ yang tidak kalah penting pengaruhnya adalah ginjal. Ginjal dalam fisiologi TCM sebagai sumber Yin dan Yang tubuh, oleh karena itu disebut juga sebagai akar Jing congenital atau keturunan. Organ yang turut serta membantu terjadinya obesitas adalah hati dan usus. Hati secara TCM berperan dalam 
memelihara Qi agar tetap lancar dalam mendistribusikan hasil olahan dari limpa. Usus sebagai organ $\mathrm{Fu}$ juga ikut serta memicu terjadinya berat badan berlebih, karena fungsinya dalam hal menampung dan memisahkan sari makanan yang masih dapat diolah dari hasil sisa metabolism di lambung (Saputra dan Agustin, 2005). Dalam penelitian ini pemilihan titi8k abdominal didasarkan pada titik simtomatis. Titik yang digunakan dalam penelitian ini yaitu CV 4 (guanyuan), CV 6 (Qihai), CV 10 (Xiawan), CV 12 (Zhongwan), ST 24 (Huaramen) dan ST 26 (Wailing). Pemilihan titik ini sesuai dengan resep haven and earth combination, leading energy back to the source combination and abdominal four gate (Wan,2009). Haven and earth copmbination merupakan kombinasi dari titik CV 12 yang merupakan titik heaven, titik CV 4 merupakan titik earth (Wan,2009). Leading energy back to the source combination terdiri dari titik CV.12, CV 10, CV 6 dan CV 4. Perpaduan dari keempat titik ini memiliki fungsi antara lain mengharmoniskan limpa dan lambung, organ yang paling bertanggung jawab menyebabkan terjadinya berat badan berlebih, tonifikasi hati dan ginjal serta memberi nutrisi seluruh tubuh. (Wan,2009). Abdominal four gate dari perpaduan ST 24 dan ST 26 secara belateral sehingga terbentuk seperti gate atau gerbang. Kombinasi dari keempat titik ini dapat menggerakkan Qi dan darah, mendistribusikan Qi dari Zang $\mathrm{Fu}$ ke seluruh tubuh serta merangsang kerja usus agar lebih maksimal (Wan, 2009). Proses penurunan berat badan pada penelitian ini mengacu pada mekanisme kerja abdominal acupuncture dalam penurunan berat badan. Melalui penusukan pada titik tersebut dapat merangsang nucleus ventromedial hypothalamic (VMH) yang dapat meningkatkan kandungan tyrosin dan dopamine pada jaringan VMH yang dapat meningkatkan kandungan tyrosin dan dopamine pada jaringan $\mathrm{VMH}$ dan menekan nafsu makan (Bin and Liu,2007). Dalam proses metabolisme penusukan pada titik akupunktur tersebut dapat meningkatkan aksi pemanasan pada jaringan lemak coklat, meningkatkan leptin hypothalamus dan gen pada reseptor leptin, menghambat sekresi neuropeptide $\mathrm{Y}$, merangsang saraf simpatik pusat, merangsang reseptor $\beta$ adrenergic pada jaringan lemak coklat yang dapat meningkatkan pelepasan fungsi protein pada lemak coklat (Bin and Liu,2007). Pada efek lokal bagian perut penusukan ini memiliki peran yang cukup besar. Distribusi penyebaran lemak yang sebagian besar berada di perut membuat metode ini cukup efektif. Dengan menggunakan titik simtomatis di perut dapat meningkatkan metabolism jaringan lemak coklat yang dapat meningkatkan pelepasan fungsi protein pada lemak coklat khususnya di perut sehingga dapat mengurangi ukuran dan membentuk kembali perut (Bin, Liu, 2007)

\section{KESIMPULAN DAN SARAN}

Dalam penelitian ini didapatkan berat badan rata - rata sebelum terapi 57,27 $\mathrm{kg}$ dan berat badan rata - rata setelah terapi ke 10 adalah 54,91. Metode abdominal akupunkture dengan menggunakan titik CV 4 (guanyuan), CV 6 (Qihai), CV 10 
(Xiawan), CV 12 (Zhongwan), ST 24 (Huaromen) dan ST 26 (Wailing). Dari semua responden yang tuntas menjalani terapi dapat menurunkan berat badan responden.

Saran yang diberikan untuk penelitian serupa yang akan datang yaitu perlu diperluasnya tempat penelitian dan melakukan randomisasi agar hasilnya dapat mempengaruhi hasil penelitian dapat lebih dipertimbangkan.

\section{DAFTAR RUJUKAN}

Hecker, H.-U., Steveling, A., and Peuker, E. 2006. Microsystem Acupuncture: The Complete Guide: Ear-ScalpMouth-Hand. Germany: Thieme New York.

Imaz, I., Martinez-Cervel, C., GarciaAlvarez, E., Sendra-Gutierrez, J. M., and Gonzalez-Enriquez, J. 2008. Safety and Effectiviness of the
Intragastric Ballon for Obesity. Springer.

Saputra, K. 2005. Akupunktur dan Moksibusi. Surabaya: Airlangga University Press.

Saputra, K., dan Idayanti, A. 2005. Akupunktur Dasar. Surabaya: Airlangga University Press.Sari, R. W. 2008. Dangerous Junk Food. Yogyakarta: $\mathrm{O}^{2}$.

Yogasmara, E., dan Lestari, P. 2010. Buku Pintar Keluarga Sehat : Panduan Praktis Hidup Sehat bagi Seluruh Anggota Keluarga. Jakarta: Gramedia Pustaka Utama.

Zuo Yanfu. 2002. Chinese Acupuncture and Moxibustion. Shanghai: Publishing House of Shanghai University. 